\title{
PERANCANGAN APLIKASI SISTEM PRESENSI SISWA BERBASIS ANDRIOD PADA SMP NEGRI 2 TINAMBUNG
}

\section{DESIGN APPLICATION SYSTEMS OF STUDENT PROGRAMS BASED ON ANDROID SMP NEGRI 2 TINAMBUNG}

\author{
Aphrizal \\ Program Studi Sistem Informasi - STMIK Dipanegara Makassar \\ Jl. Perintis Kemerdekaan Km. 9, Tamalanrea Makassar 90000 Indonesia \\ aphrydpn@yahoo.com \\ Naskah Diterima: 17 November 2016; Direvisi : 16 Agustus 2017; Disetujui : 22 Agustus 2017
}

\begin{abstract}
Abstrak
Perilaku membolos sekolah pada remaja saat ini dapat disebabkan oleh beberapa factor-faktor personal atau siswa itu sendiriantara lain hilangnya minat akademik siswa, kondisi ketinggalan pelajaran, atau karena kenakalan remaja, serta faktor keluarga misalnya karena kurangnya partisipasi orang tua/wali dalam pendidikan anak. Absensi manual yang diterapkan saat ini masih menggunakan surat sehingga butuh jangka waktu yang ditentukan sekolah agar orang tua dapat mengetahui status anaknya. Dengan penerapan sistem presensi siswa berbasis android orang tua/wali siswa dapat memantau anaknya secara berkala berdasarkan jam pelajaran. Aplikasi ini dibuat dalam bentuk mobile dan website. Metode yang digunakan adalah rancang bangun pengambilan data kegiatan secara langsung dan data dari pihak sekolah menggunakan perangkat penyimpanan data. Aplikasi ini menggunakan koneksi GPRS/HSDPA atau Wifi sebagai media konektivitasnya Aplikasi ini dapat digunakan oleh guru dan orang tua/wali siswa serta mampu memberikan informasi tentang status presensi siswa bagi orang tua/wali siswa secara online.
\end{abstract}

Kata kunci : Sistem, Presensi, Android

\begin{abstract}
Nowdays, behavior skipped school on teenagers can betriggered by several factors such as personal or students themselves are associated with loss of academic interest of students, the conditions to miss class, or because of juvenile delinquency, also family factor that play a role in the effect of these include lack of participation parents guardians in the education of the child, absence is currently implemented using the mail so it take a prescribed period of school that allowing parents/guardians to know the status of their children. This android based student presence application the parents / guardiansto observe their children depended on classes periodic this application is provided in mobile and website design. The methods are the design activities direct data collection and data from the school authorities using a data storage device. This application using GPRS / HSDPA or WiFi as media connectivity. Tthis application can be used by teachers and parents / guardians of the students and is able to provide online information on the presence status of students for parents / guardians of students.
\end{abstract}

Keywords: Systems, Presence, Android 


\section{PENDAHULUAN}

Perkembangan teknologi komputer sangat berperan dan membantu pekerjaan manusia dalam segala bidang sehingga menuntut manusia untuk memahami dan menguasainya agar dapat mencapai tujuan yang dikehendakinya. Institut merupakan salah satu bidang vital yang memanfaatkan teknologi komputer. Tanpa teknologi komputer lembaga pendidikan dapat dikatakan belum cukup untuk mendukung proses belajar mengajar yang baik.

Salah satu komponen menyusun tata tertib di dalam pendidikan adalah presensi atau daftar kehadiran siswa. Presensi adalah suatu kegiatan mencatat kehadiran setiap siswa di sekolah. Tujuan adanya presensi secara umum adalah untuk mengetahui kehadiran dan ketidak hadiran peserta didik. Perizinan untuk tidak masuk sekolah atau meninggalkan pelajaran, serta menertibkan siswa/siswi agar selalu hadir disekolah tepat waktu dan memastikan apakah siswa/siswi mengikuti kegiatan belajar mengajar secara efektif. Dengan demikian dapat dikatakan bahwa presensi memiliki peran yang sangat penting dalam menertibkan sekolah.

SMP Negeri 2 Tinambung adalah salah satu lembaga pendidikan yang mendidik siswanya untuk lebih unggul dan berprestasi. Sistem presensi yang ada di SMP Negeri 2 Tinambung sama seperti sekolah lain pada umumnya, yaitu di kelas dengan menggunakan kertas absen dan apabila ada salah seorang siswa yang tidak mengikuti mata pelajaran/tidak hadir, maka pihak sekolah akan membuat surat keterangan dari sekolah dan mengirimkannya kepada orang tua siswa tersebut. Dengan adanya sistem presensi berbasis android maka para orang tua siswa akan dapat mengetahui keberadaan anaknya di kelas pada saat jam pelajaran berlangsung di SMP Negeri 2 Tinambung.

Permasalahan yang dihadapi SMP Negeri 2 Tinambung adalah banyaknya siswa yang tidak memasuki mata pelajaran atau perilaku membolos tanpa sepengetahuan orang tua/wali siswa pada saat jam pelajaran berlangsung, faktor penyebab munculnya perilaku membolos sekolah pada remaja ini dapat dikelompokkan menjadi 3 yaitu faktor sekolah, personal, serta keluarga. Faktor sekolah yang beresiko meningkatkan munculnya perilaku membolos pada remaja antara lain kebijaksanaan mengenai pembolosan yang tidak konsisten, interaksi yang kurang antara orang tua/wali dengan pihak sekolah, guru-guru yang tidak suportif, atau tugas-tugas sekolah yang kurang menantang bagi siswa.

Faktor personal misalnya terkait dengan menurunnya motivasi atau hilangnya minat akademik siswa, kondisi ketinggalan pelajaran, atau karena kenakalan remaja seperti konsumsi alkohol dan minuman keras. Sedangkan faktor keluarga meliputi pola asuh orang tua atau kurangnya partisipasi orang tua dalam pendidikan anak.

Adapun beberapa penelitian yang terkait yaitu: (1) Perancangan Aplikasi Sisem Presensi Mahasiswa Menggunakan $Q R$ Code pada Sistem Operasi Android (Setyawan, 2015). Perbedaan penelitian terletak pada metode yang digunakan yaitu QR Code merupakan evolusi kode batang dari satu dimensi menjadi dua dimensi. (2) Sistem Informasi Presensi Mahasiswa Menggunakan Near Field Communicatioan (NFC) Berbasis Android ClientServer di Prodi Sistem Informasi Fakultas Teknik (Muslim, 2014). Perbedaan penelitian terletak pada aplikasi yang dibangun tidak mendukung untuk semua versi Android dan juga memerlukan adanya fitur NFC untuk dapat melakukan presensi 
menggunakan Radio Frequency Identification (RFID).

Sebuah nama untuk sistem operasi pada suatu gadget seperti komputer tablet, smartphone dan telepon cellular disebut Android. Sistem operasi yang digunakan berbasis Linux. Dari waktu ke waktu Android terus meningkatkan kinerjanya, sehingga memunculkan versi-versi terbaru dari Android. Android adalah sistem operasi sumber terbuka dan lisensi perizinan pada android memungkinkan perangkat lunak dimodifikasi dan didistribusikan secara bebas.

Sistem presensi siswa berbasis Android dilakukan untuk meningkatkan kedisiplinan terhadap siswa. Mengefisienkan waktu dan tenaga sekaligus membudayakan teknologi komputer pada berbagi kalangan pengguna khususnya staf pengajar (guru). Presensi manual yang diterapkan sekolah saat ini menggunakan surat, sehingga butuh jangka waktu yang ditentukan di sekolah agar dapat mengetahui status anaknya di sekolah, ketika siswa tidak mengikuti pelajaran tanpa keterangan dalam waktu yang ditentukan maka sekolah akan mengirim surat kepada orang tua siswa.

Menurut Max William (Nanlohy M.W, Suprihadi, 2012) sistem informasi presensi sekolah adalah sistem informasi untuk mencatat (manual atau elektronik), mengelola, dan melaporkan kehadiran sarta ketidakhadiran siswa. Menurut (Kadir, 2014) aplikasi itu sebenarnya adalah program, tetapi berbeda dari titik pandang. Program adalah istilah yang biasa dipakai oeh pembuat program, sedang aplikasi adalah istilah dari sisi pemakai (user). Sistem Operasi Android adalah sistem operasi berbasis Linux yang dirancang untuk perangkat seluler layar sentuh seperti telepon pintar dan computer tablet. (Hermanto D.A., 2014)
Menurut (Kadir, 2014). Algoritma terkadang disajikan dalam bentuk diagram alir (flowchart). Menurut (Yulianto A.A, 2009) Unified Modeling Language (UML) merupakan sebuah standarisasi bahasa pemodelan untuk pembangunan perangkat lunak yang dibangun dengan menggunakan teknik pemrograman berorientasi objek. Menurut (Kurniawan, Hendra, Eri Mardiani, 2011) black box testing, dilakukan tanpa pengetahuan detail struktur internal dari sistem atau komponen yang dites. Juga disebut sebagai behavior testing, specification-based testing, input/output testing atau functional testing.

Menurut (Ambon.Nazaruddin, 2011), Android adalah sebuah sistem operasi perangkat mobile berbasis Linux yang mencakup sistem operasi, middleware, dan aplikasi. Android adalah sistem operasi untuk telepon selular yang berbasis Linux. Menurut (Kurniawan, 2013) Java adalah salah satu bahasa pemrograman tingkat tinggi yang mendekati bahasa manusia. Menurut (Putra, 2009) perkembangan internet tidak terlepas dari Web atau World Wide Web, disingkat www. Menurut (Beta Sidik, 2014) PHP secara umum dikenal sebagai bahasa pemrograman script yang membuat dokument HTML secara on the fly yang dieksekusi di server web. Dokumen HTML yang dihasilkan dari suatu apikasi bukan dokumen HTM yang dibuat dengan menggunakan editor teks atau editor HTML. Menurut Kadir (2009) MySQL merupakan software yang tergolong sebagai DBMS (Database management System) yang bersifat open source.

Adapun rumusan masalah dalam penelitian ini adalah bagaimana orang tua/wali siswa bisa mengontrol kehadiran/keberadaan anaknya pada saat jam belajar berlangsung di sekolah.

Tujuan dan manfaat penelitian adalah 1) merancang sebuah aplikasi mobile dan website yang 
memberikan kemudahan kepada orang tua/wali siswa untuk memantau anaknya yang berada di sekolah khususnya di dalam kelas pada saat jam pelajaran. 2) Menambah pengetahuan penyusun tentang bagaimana merancang aplikasi pada sistem operasi berbasis Android. 3) Dapat mengetahui kondisi kehadiran anaknya di kelas. 4) Dapat dijadikan bahan acuan untuk pengembangan teknologi informasi sesuai dengan kebutuhan akademik.

\section{METODE}

Untuk menyempurnakan data-data yang dibutuhkan dalam rangka penyusunan penelitian ini, maka penulis mengumpulkan data melalui dua cara yaitu: (1) Secara langsung melalui wawancara langsung dengan pegawai/staf sekolah. (2) Secara tidak langsung, artinya penulis berpedoman pada buku-buku yang berkaitan dan berhubungan langsung dengan materi yang dilaksanakan. Tempat penelitian dilaksanakan di SMP Negri 2 Tinambung Kabupaten Polewali-Mandar Sulawesi Barat.

Tahapan-tahapan atau langkah-langkah pokok yang dilakukan dalam kegiatan penelitian terdiri dari: (1) Pengumpulan data penelitian dikumpulkan sesuai dengan rancangan penelitian yang telah ditentukan. (2) Analisis data, menguraikan proses presensi siswa di kelas dan mencatat secara sistematis transkip-transkip wawancara, catatan lapangan, dan data-data referensi lain agar dapat menyajikan hasil penelitiannya. (3) Desain aplikasi, merupakan langkah utama untuk membuat sebuah aplikasi berdasarkan hasil pengumpulan dan analisis data yang telah dilakukan di lokasi penelitian. (4) Pembuatan aplikasi, yaitu mengimplementasikan ke program desain yang sudah didapatkan dan mengolah berbagai data untuk membentuk sebuah aplikasi yang akan direpresentasikan. (5) Pengujian aplikasi, merupakan proses menjelaskan dan mengevaluasi sebuah aplikasi untuk mendapatkan informasi dari aplikasi atau layanan yang sedang diuji. (6) Implementasi, yaitu penerapan dan pemeliharaan aplikasi yang telah dibuat untuk diaplikasikan di lokasi objek penelitian.

\section{HASIL DAN PEMBAHASAN}

\section{Perancangan}

Rancangan sistem berguna untuk memberikan gambaran kepada pemakai tentang sistem yang baru. Rancangan sistem secara umum merupakan persiapan dari rancangan sistem secara terperinci.

\section{Use Case Diagram}

Use case diagram berfungsi untuk menjelaskan manfaat sistem jika dilihat menurut pandangan orang yang berada di luar sistem (actor). Use case mendeksripsikan fungsi-fungsi yang disediakan oleh sistem, sedangkan actor (aktor) merupakan individu atau seseorang yang berinteraksi dengan sistem. 


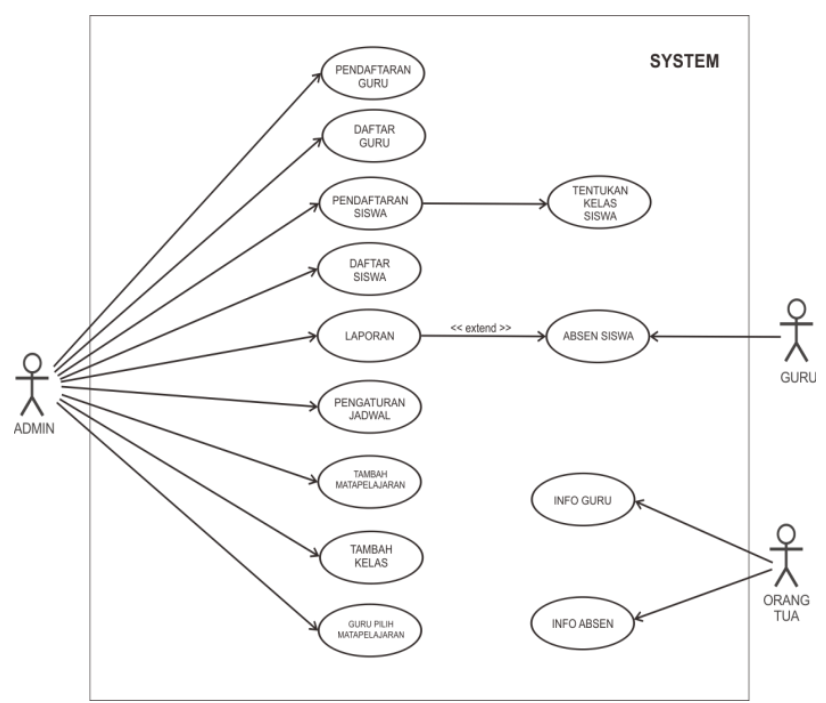

Gambar 1 Use case diagram sistem presensi siswa

Penjelasan use case diagram di atas ialah sebagai berikut :

1. Pendaftaran guru yaitu admin mendaftarkan guru sebagai user guru

2. Daftar guru yaitu admin menampilkan daftar guru

3. Pendaftaran siswa yaitu admin mendaftarkan siswa sebagai user bagi orang tua/wali siswa.

4. Tentukan kelas siswa yaitu admin menentukan kelas untuk siswa setelah didaftarkan

5. Daftar siswa yaitu admin menampilkan daftar siswa

6. Laporan yaitu admin menampilkan daftar absen guru yang belum absen dan melakukan Absen siswa, dan bila guru sudah mengabsen maka laporan tidak akan menampilkan daftar absen guru.

7. Pengaturan jadwal yaitu admin melakukan penambahan jadwal mengajar guru

8. Tambah mata pelajaran yaitu admin menambahkan mata pelajaran baru

9. Tambah kelas yaitu admin akan menambahkan kelas baru bila sekolah mendapatkan siswa yang lebih banyak dari tahun yang sebelumnya
10. Guru pilih mata pelajaran yaitu admin akan menentukan mata pelajaran bagi guru

11. Absen siswa yaitu guru akan melakukan presensi pada siswa

12. Info guru yaitu orang tua dapat menampilkan profil guru yang mengajar pada mata pelajaran siswa.

13. Info absen yaitu orang tua dapat melihat status absen siswa yang sedang belajar di kelas

\section{Class Diagram}

Setiap objek merupakan instance dari suatu kelas, dimana kelas tersebut menggambarkan properti dan behavioir dari setiap jenis objek.

Sebuah diagram kelas menggambarkan kelas yang terdapat pada sistem dan hubungannya dengan kelas lainnya. Class diagram berikut ini adalah class diagram pada sistem yang menunjukkan semua proses:

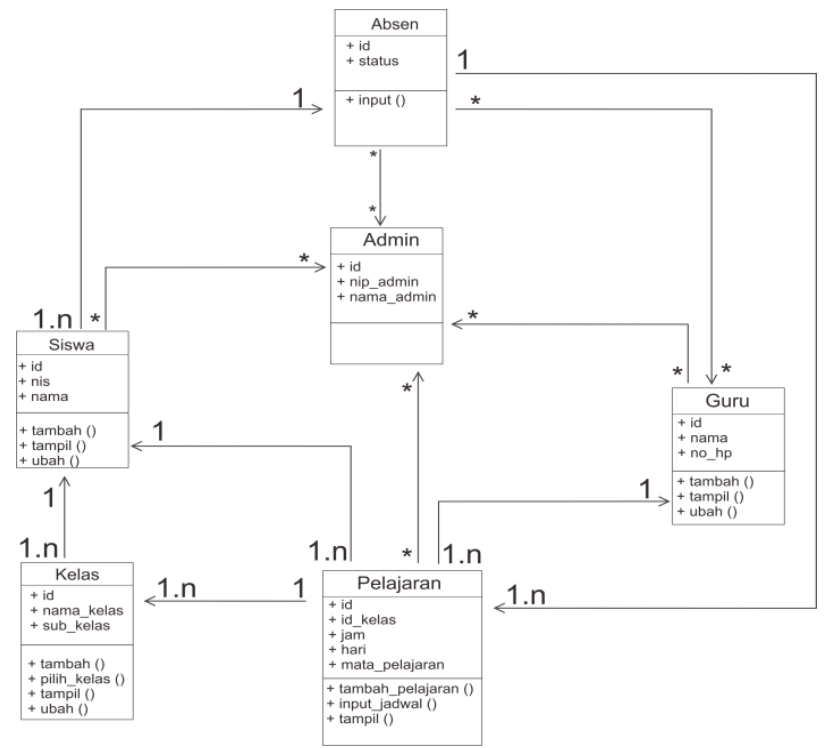

Gambar 2 Class diagram proses sistem

Gambar class diagram pada Gambar 2 proses sistem di atas, menjelaskan tentang kelas yang terdapat pada sistem berdasarkan proses yang ada di dalam sistem. 
Class admin mendapatkan segala operasi dari setiap class. Class guru memiliki operasi tambah() untuk dapat menambahkan data, tampil() untuk dapat menampilkan data, dan ubah() untuk dapat mengatur data yang berdasarkan asosiasi (hubungan) dari class admin. Class siswa, kelas dan pelajaran memiliki operasi yang sama. Class absen memiliki operasi input() untuk dapat menginput data absen dan menghubungkan class guru(), class pelajaran() berdasarkan attribut dan operasi lainnya.

Class kelas memiliki operasi pilih_kelas() yang menentukan kelas siswa dengan hubungan dari class siswa yang menambahkan beberapa attribut di class siswa.

\section{Activity Diagram}

Activity Diagram yang dirancang menggambarkan aliran activity atau proses dalam sistem yang dirancang. Dari use case yang ada, maka akan dibagi menjadi beberapa activity diagram yang menggambarkan proses yang terjadi dalam sistem. Terdiri dari activity diagram input data guru dan siswa, activity diagram input kelas dan pelajaran, activity diagram guru pilih mata pelajaran, activity diagram absen siswa sebagai guru, dan activity diagram absen sebagai admin.

\section{Activity Diagram Input Data Guru dan Siswa}

Activity diagram input data guru dan siswa yang dirancang menggambarkan aliran atau proses penambahan data guru dan siswa yang dilakukan oleh admin. Berikut adalah gambaran activity diagram input data guru dan siswa.

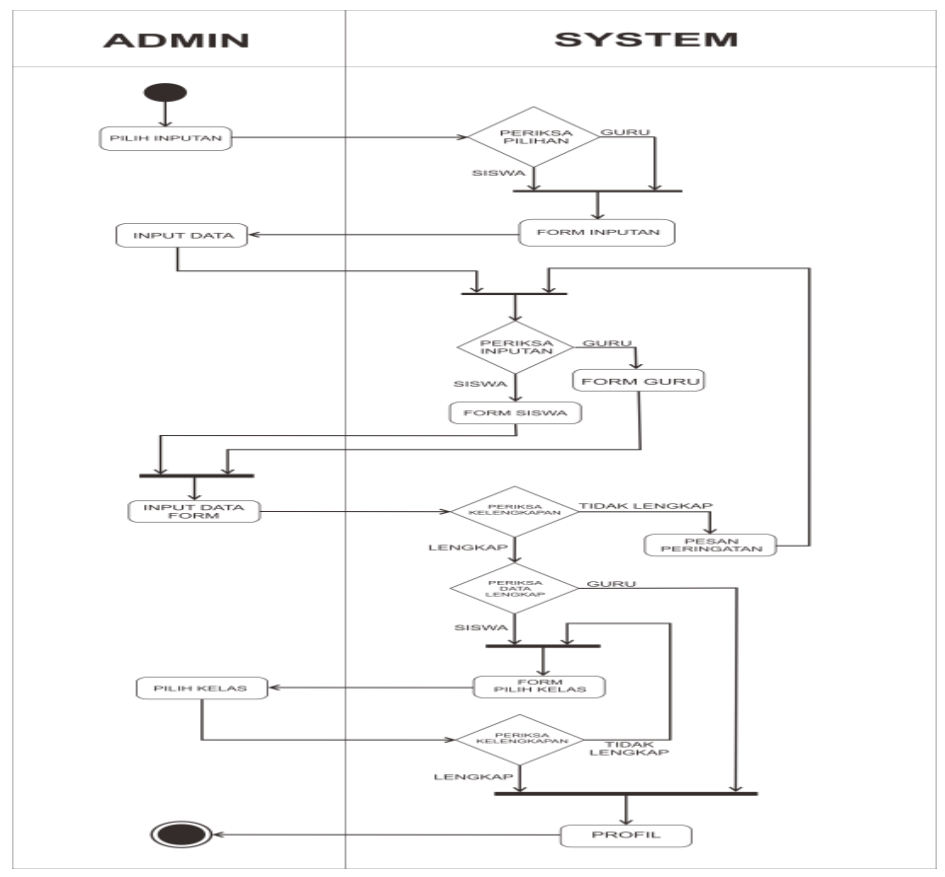

Gambar 3 Activity diagram input data guru dan siswa

Gambar diagram activity di atas menjelaskan tentang proses kerja admin menginputkan data guru dan siswa di dalam sistem.

Admin memilih pilihan input (guru atau siswa) setelah itu sistem akan memeriksa inputan yang dipilih, bila yang akan dipilih adalah guru sistem akan menyeleksi pilihan yang dipilih begitupun juga dengan siswa, terdapat form inputan masing-masing pilihan, Admin akan input data yang dimiliki formform inputan di sistem kemudian menyeleksi inputan (guru atau siswa), bila periksa inputan adalah guru maka akan memunculkan form guru begitupun juga 
dengan siswa, Admin akan menginput data form dan mengirim ke sistem setelah itu akan diseleksi apakah hasil inputan lengkap atau tidak lengkap periksa kelengkapan). Apabila tidak lengkap maka akan dikembalikan ke periksa inputan dan akan menampilkan form inputan dan apabila lengkap maka akan dilanjutkan ke step selanjutnya yaitu penyelekisan data yang lengkap. Jika data guru sudah sudah memenuhi maka akan menampilkan profil kemudian selesai dan bila data siswa yang sudah memenuhi sistem akan menampilkan form pilih kelas dan dikembalikan ke admin untuk pemilihan kelas (pilih kelas) setelah itu dikirim ke admin untuk periksa kelengkapan apabila tidak lengkap maka akan dikembalikan ke form pilih kelas dan apabila lengkap maka menuju ke profil dan selesai.

Setelah admin melengkapi semua isian yang diperlukan untuk mendaftarkan guru dan siswa, maka guru dan siswa tersebut telah terdaftar ke dalam sistem.

\section{Sequence Diagram}

Sequence diagram adalah diagram yang menggambarkan interaksi antar objek dan mengindikasikan komunikasi diantara objek-objek yang ada dalam sistem. Diagram ini juga menunjukkan serangkaian pesan yang dipertukarkan oleh objek-objek yang melakukan suatu tugas atau aksi tertentu. Objek-objek tersebut kemudian diurutkan dari kiri ke kanan, aktor yang menginisiasi interaksi biasanya ditaruh di paling kiri dari diagram. Di dalam perancangan penulis akan membagi tiga bagian sequence diagram, yang pertama adalah sequence diagram guru yang selaku pengguna di dalam presensi siswa, kedua adalah sequence diagram orang tua yaitu pengguna yang akan mendapatkan informasi status presensi dari guru yang mengabsen siswa, dan ketiga adalah sequence diagram admin, yang mengelolah segala fungsi atau memiliki hak sepenuhnya di dalam sistem.

\section{Sequence Diagram Guru}

Sequence diagram guru yang dirancang, untuk menggambarkan secara detail urutan presensi siswa yang dilakukan oleh guru dalam sistem untuk mencapai tujuan dari use case yang terjadi antar kelas dan operasi apa saja yang terlibat dalam sistem. Berikut gambar dari sequence diagram guru

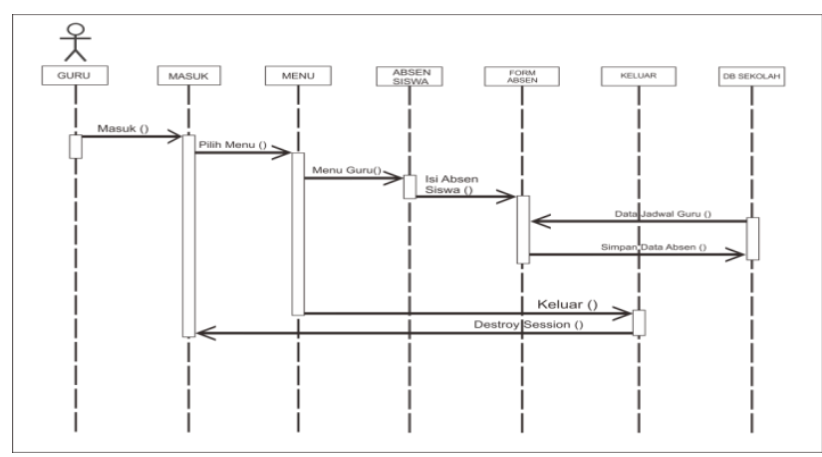

Gambar 4 Sequence diagram guru

Gambar sequence diagram guru di atas dapat dijelaskan bahwa mulai dari guru melakukan login masuk, setelah masuk guru akan memilih menu, absen siswa kemudian akan mendapatkan data jadwal guru dari databse dan melengkapi isian yang ada di form absen setelah itu simpan hasil presensi ke database, adapun fungsi keluar() yang ada di menu untuk keluar dan kembali ke masuk.

\section{Perancangan Interfaces}

Berikut adalah hasil perancangan interface dari pembuatan sistem presensi berbasis Android di AMP Negeri 2 Tinambung.

\section{Perancangan Tampilan Utama Admin}

Perancangan tampilan menu dirancang untuk menampilkan tampilan muka admin dengan sistem setelah admin login, admin akan mendapatkan tampilan tentang guru-guru yang belum melakukan presensi, selanjutnya adalah gambaran tampilan 
interface utama admin:

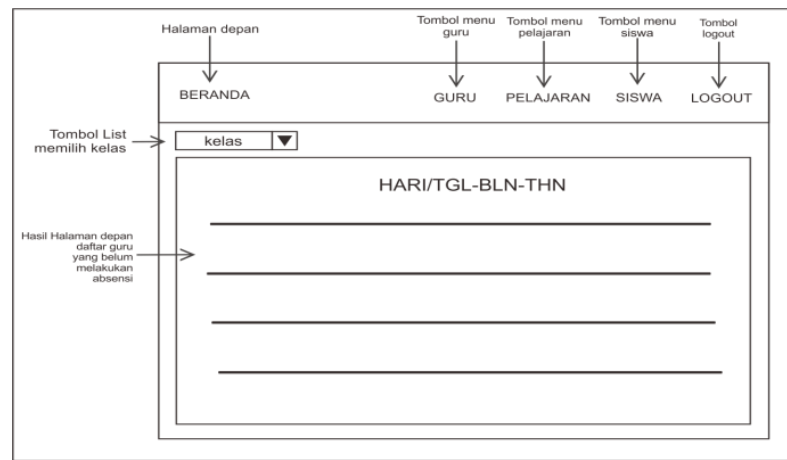

Gambar 5 Tampilan utama admin

\section{Perancangan Tampilan Presensi (Admin)}

Perancangan tampilan presensi yang dilakukan admin dirancang untuk melakukan presensi sebagai pengganti guru yang tidak melakukan presensi (tidak hadir diwaktu jam mengajar), berikut adalah gambaran dari Tampilan presensi oleh admin :

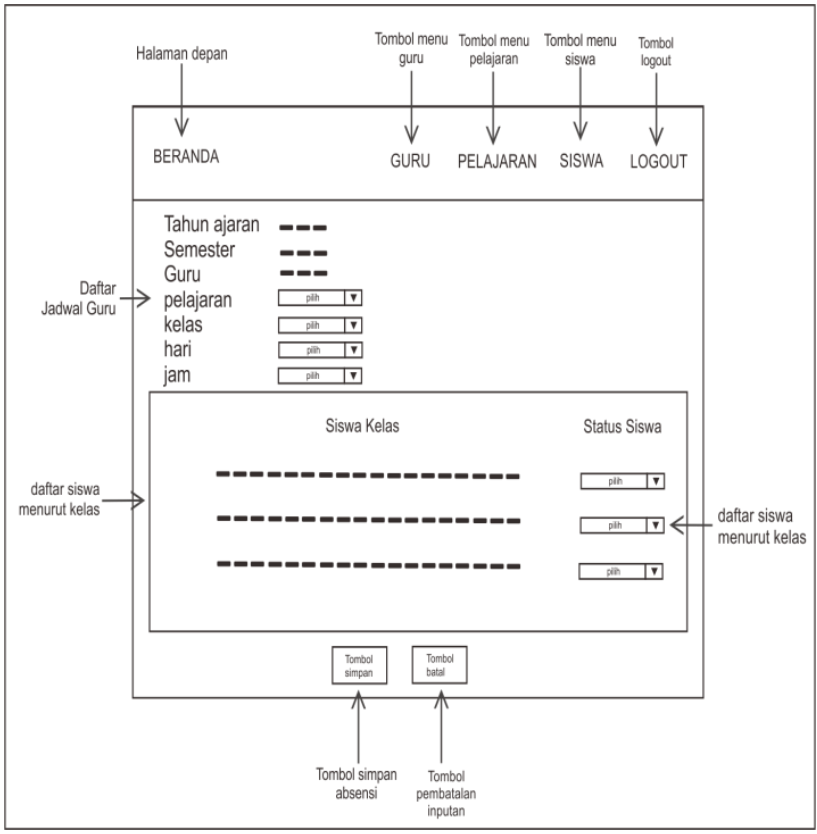

Gambar 6 Tampilan presensi oleh admin

Perancangan Tampilan Menu Guru oleh Admin

Perancangan tampilan menu guru yang dilakukan oleh admin dirancang untuk melakukan beberapa proses seperti, menambah data guru menampilkan data guru, dan menampilkan profil guru. Berikut adalah gambaran dari tampilan menu guru dan daftar guru (tampilan guru-guru yang sudah terdaftar) :

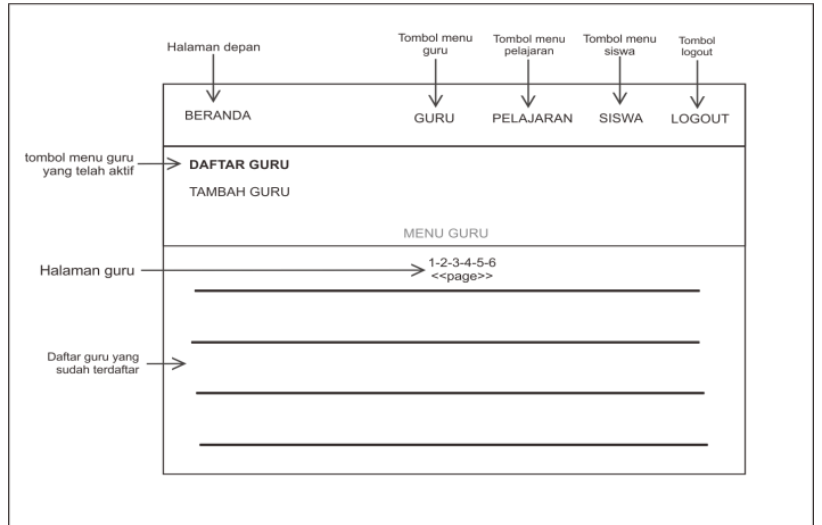

Gambar 7 Tampilan menu guru (daftar guru) oleh admin

\section{Perancangan Tampilan Profil Guru oleh admin}

Rancangan tampilan profil guru yang dirancang untuk admin dapat mengolah guru, seperti delete, edit, dan menentukan mata pelajaran guru. Berikut adalah gambaran dari tampilan profil guru :

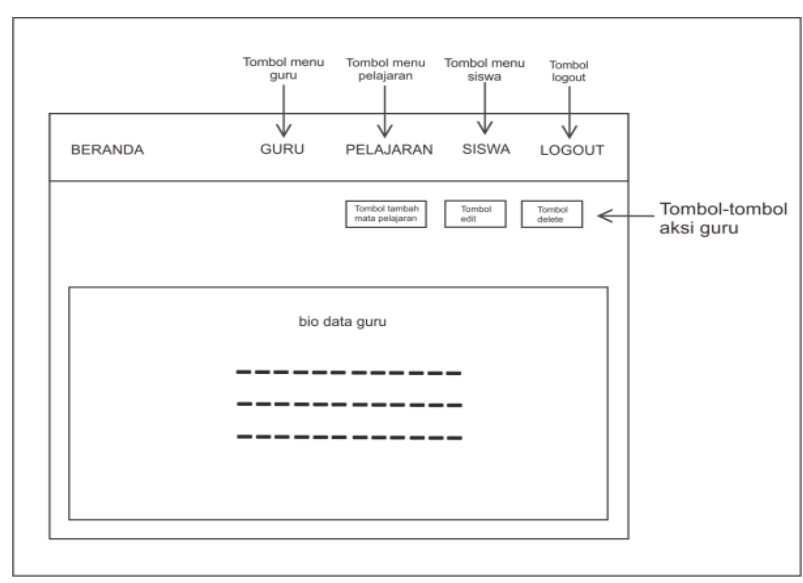

Gambar 8 Tampilan profil guru oleh admin

\section{Perancangan Tampilan Pilih Mata Pelajaran guru oleh admin}

Dalam profil guru terdapat sebuah rancangan tampilan untuk menentukan mata pelajaran guru, tampilan ini dirancang seperti yang terdapat pada gambar di halaman selanjutnya : 


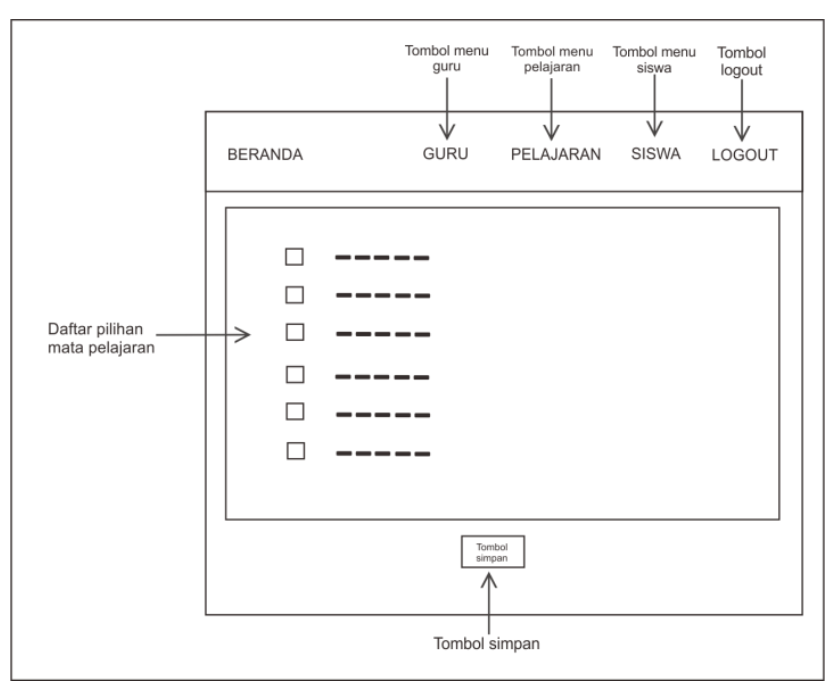

Gambar 9 Tampilan pilih mata pelajaran guru oleh admin

\section{Perancangan Tampilan Tambah Guru oleh admin}

Tampilan rancangan ini dirancang untuk dapat menambahkan data guru baru serta menjadi pengguna bagi sistem ini Berikut adalah gambaran dari rancangan tampilan menambahkan guru baru yang dilakukan oleh admin :

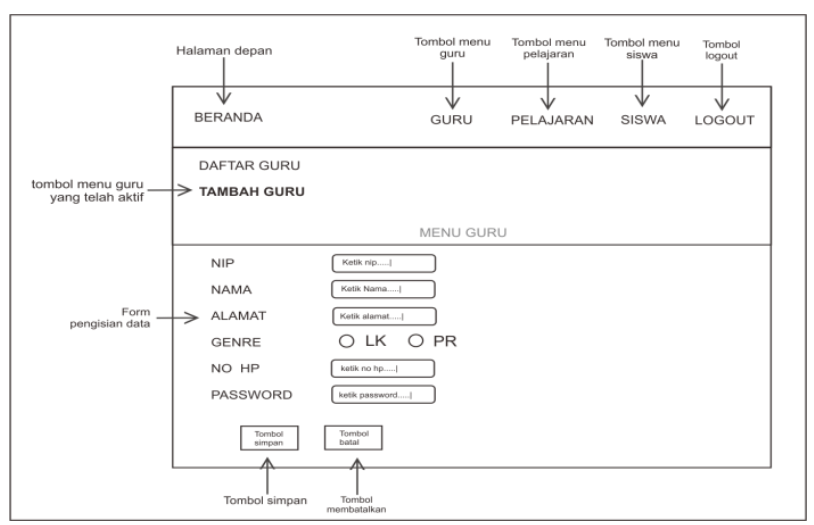

Gambar 10 Tampilan tambah guru

Perancangan Tampilan Menu Pelajaran oleh Admin

Perancangan interface menu pelajaran dirancang untuk mengolah mata pelajaran di dalam system. Berikut ini adalah gambar tampilan perancangan menu pelajaran :

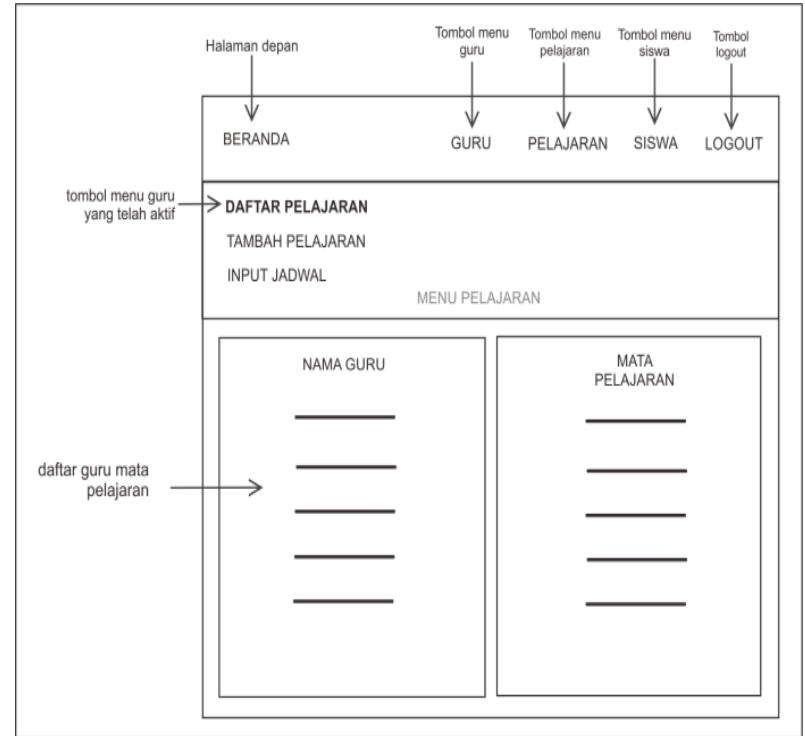

Gambar 11 Tampilan daftar guru mata pelajaran oleh admin

\section{Pengujian}

Berdasarkan pengujian Blackbox yang telah dilakukan, maka secara umum hasil pengujian aplikasi dapat disimpulkan sebagai berikut:

Tabel 1 Pengujian Blackbox

\begin{tabular}{cccc}
\hline No & Skenario & Hasil yang & Ket \\
& Penjujian & Diharapkan & \\
&
\end{tabular}

1 Menampilkan daftar Berhasil meng- Valid guru belum input data melakukan absen absen siswa dan menggantikan guru untuk mengabsen siswa.

2 Menampilkan Status Berhasil meng- Valid Siswa Berdasar input data kan nis siswa dan absen siswa menampilkan info guru berdasarkan mata pelajaran

3 Menampilkan Status Berhasil meng- Valid Siswa Berdasarkan input data nis siswa dan absen siswa menampilkan info guru berdasarkan mata pelajaran 


\section{Hasil Pengujian}

Berdasarkan tiga pengujian yaitu, presensi pertama yang dilakukan oleh guru untuk menginput status siswa-siswa, presensi kedua yang dilakukan oleh admin apabila seorang guru tidak dapat hadir di sekolah maka sang admin akan menggantikan guru untuk menginput status siswa-siswa, dan info status siswa yang dilakukan oleh orang tua/wali siswa untuk mengetahui status belajar sang anak di sekolah.

\section{PENUTUP}

Aplikasi yang dirancang ini mampu memberikan informasi tentang kehadiran anak saat jam belajar siswa bagi orang tua/wali siswa secara online. Dengan adanya fasilitas aplikasi mobile dan website ini maka akan dapat memudahkan mengirim/mendapatkan informasi dari pihak sekolah..

\section{UCAPAN TERIMA KASIH}

Penulis mengucapkan banyak terima kasih kepada SMP Negeri 2 Tinambung, atas kerjasamanya dalam memberikan ijin pengambilan data. Terima kasih juga kepada rekan-rekan dosen atas motivasi selama penelitian hingga selesai. Terima kasih kepada istri dan anak tercinta atas pengertian dan dukungannya kepada peneliti.

\section{DAFTAR PUSTAKA}

Ambon. Nazaruddin, S. H. (2011). Pemrograman Aplikasi Mobile Smartphone dan Tablet PC
Berbasis Android. Bandung: Informatika.

Hermanto D.A. (2014). Rancangan Bangun Aplikasi Berbasis Android Pencarian Lokasi Universitas Di Kota Semarang Location-Based Service. Retrieved December 20, 2015, from http://eprints.dinus.ac.id/13457

Kadir, A. (2009). Belajar Database Menggunakan $M y S Q L$. Yogyakarta: CV Andi Offset.

Kadir, A. (2014). Buku Pertama Belajar Pemrograman Java Untuk Pemula. Jakarta: PT Buku Seru.

Kurniawan, Hendra, Eri Mardiani, dan N. R. (2011). Aplikasi Penjualan dengan Program Java Netbens, Xampp, dan iReport. Jakarta: PT. Gramedia Pustaka Utama.

Kurniawan, A. (2013). Pemrograman Java Untuk Pemula. Retrieved January 20, 2016, from http://www.slideshare.net/agusk2007/sampemandiri-java

Muslim, F. I. (2014). Sistem Informasi Presensi Mahasiswa Menggunakan Near Field Communicatioan (NFC) Berbasis Android Client-Server. Jurnal Informatika., 5(1).

Nanlohy M.W, Suprihadi, S. A. . (2012). Perancangan Sistem Absensi Siswa Berbasis SMS Gateway SMU Negeri 2.

Putra, E. (2009). Summary Desain Sistem Isolasi Ruang Penyimpanan Es dan Ikan untuk Kapal Ikan 306 . Surabaya.

Setyawan, A. H. (2015). Perancangan Aplikasi Sisem Presensi Mahasiswa Menggunakan Qr Code pada Sistem Operasi Android. Jurnal Informatika, 4(2 Maret).

Sidik, B. (2014). Pemrograman Web dengan PHP. Bandung: Informatika.

Yulianto A.A. (2009). Analisis Dan Desain Sistem Informasi. Bandung. 